\title{
ANTIMICROBIAL ACTIVITY OF CHITOSAN 2\% AND OXYGENIZING DENTURE CLEANSER ON PROHIBITING STREPTOCOCCUS MUTANS GROWTH AT ACRYLIC HEAT-CURED RESINS PLATE
}

\author{
EFEK ANTIMIKROBA KITOSAN $2 \%$ DAN PEMBERSIH GIGI TIRUAN BEROKSIDA DALAM \\ MENGHAMBAT PERTUMBUHAN STREPTOCOCCUS MUTANS PADA LEMPENG RESIN \\ AKRILIK POLIMERISASI PANAS
}

\author{
Angela Evelyna, Dahlia Sutanto, and Astuti Nadapdap \\ Faculty of Dentistry \\ Maranatha Christian University \\ Jl.Prof. drg. Surya Sumantri, M.P.H. No.65, Bandung 40164, Indonesia \\ E-mail: angela_evelyna@yahoo.co.id
}

\begin{abstract}
Heat-cured acrylic denture base-plate may act as reservoir for Streptococcus mutans (all species name must be in italics) colonies, this condition may lead to denture stomatitis. One of denture cleansing method that frequently used is by immersion (of what?) in oxygenizing denture cleansers that has several disadvantages such as high cost and biocompatibility issue regarding chemical synthetic component of the solution. Chitosan is a natural compound that has antibacterial nature. The most commonly percentage of chitosan used for biomedical purposes is $2 \%$. The objective of this study is to evaluate the antimicrobial effectivity of chitosan $2 \%$ on acrylic heat-cured plates and compare it with oxygenizing denture cleansers. Aquadest was used as control. Fifteen acrylic heat-cured plates $(10 \times 10 \times 2 \mathrm{~mm})$ immersed in Streptococcus mutans suspensions at temperature $37^{\circ} \mathrm{C}$ for 48 hours of 3 different solutions. The solutions were vortexed and put into (Brain Heart Infusion Agar) medium. Streptococcus mutans colonies were counted manually. The result shows, that Streptococcus mutans colonies on aquadest group was $269.75 \mathrm{CFU} /$ plate, followed by oxygenizing denture cleanser with $11 \mathrm{CFU} /$ plate), and chitosan $2 \%$ group with $0.4 \mathrm{CFU} /$ plate, respectively. Data were analysed with Kruskal-Wallis non-parametric test followed by Mann-Whitney test shows of $\mathrm{p}=0.012(\mathrm{p}<0.05)$. There were no statistically significant different of antimicrobial activity between chitosan $2 \%$ and oxygenizing denture cleanser. The result demonstrated that chitosan $2 \%$ solution was more effective to prohibit the growth of Streptococcus mutans colonies on acrylic heat cured plates, however a statistically significant difference between the two groups was not observed.
\end{abstract}

Keywords: chitosan, denture cleanser, streptococcus mutans

\begin{abstract}
Abstrak
Basis gigi tiruan resin akrilik dapat menjadi tempat berkembang-biaknya koloni Streptococcus mutans. Kondisi ini dapat mengakibatkan terjadinya stomatitis gigi tiruan. Salah satu metode pembersihan gigi tiruan yang banyak dilakukan adalah melalui perendaman pada pembersih gigi tiruan beroksida. Metode ini memiliki beberapa keterbatasan yaitu antara lain harganya yang relatif mahal dan isu biokompatibilitasnya terkait kandungan bahan kimiawi sintetik didalamnya. Kitosan merupakan bahan alami yang memiliki sifat antibakteri. Persentase komposisi larutan kitosan yang biasa digunakan adalah $2 \%$. Tujuan dari penelitian ini adalah untuk mengevaluasi efektivitas antimikroba larutan kitosan $2 \%$ pada pelat resin akrilik polimerisasi panas dan membandingkannya dengan pembersih gigi tiruan beroksida. Akuades digunakan sebagai kontrol. Lima belas pelat resin akrilik polimerisasi panas (10 x 10 × $2 \mathrm{~mm})$ dicelup ke dalam suspensi Streptococcus mutans pada suhu $37^{\circ} \mathrm{C}$ selama 48 jam dan direndam pada tiga macam larutan berbeda. Larutan tersebut kemudian divibrasi dan diletakkan pada media (Brain Heart Infusion Agar). Setelah itu, koloni Streptococcus mutans dihitung secara manual. Hasil menunjukkan rerata koloni Streptococcus mutans tertinggi terdapat pada kelompok control (269,75 CFU/plate), diikuti oleh kelompok pembersih gigi tiruan beroksida (11 CFU/plate), dan kelompok kitosan 2\% (0,4 CFU/plate). Data yang didapat dianalisis menggunakan uji non-parametrik Kruskal-Wallis dilanjutkan uji MannWhitney memperlihatkan $\mathrm{p}=0,012(\mathrm{p}<0,05)$. Tidak terdapat perbedaan signifikan antara kitosan $2 \%$ dan pembersih gigi tiruan beroksida. Simpulan dari penelitian ini adalah bahwa larutan kitosan $2 \%$ memiliki efek signifikan dalam
\end{abstract}


menghambat pertumbuhan koloni Streptococcus mutans pada pelat resin akrilik polimerisasi panas walaupun tidak berbeda secara signifikan dengan bahan perendam gigi tiruan beroksida.

Kata kunci: kitosan, pembersih gigi tiruan, Streptococcus mutans

\section{INTRODUCTION}

An adequate dentition is of importance for wellbeing and life quality. Despite advances in preventive dentistry, edentulism is still a major public health problem worldwide. Edentulism may disturb the functions of stomatognathic system such as mastication, phonetics and aesthetics. Lots of teeth may preclude eating favourite foods as well as limit in-take of favourite foods. Poor oral health and loss of teeth not only affects dietary intake and nutrition status but also compromise general health of patients. Denture is the best solution for edentulous person. Removable partial denture is the major choice of partially edentulous patient. ${ }^{1}$

Removable partial denture consists of many components which are artificial teeth, minor connector, major connector, direct retainer, indirect retainer, occlusal rest, and denture baseplate. One of the components that have an intact contact with oral mucosa is denture baseplate. Denture baseplate can be constructed of several things, but most denture bases have been fabricated using acrylic (polymethyl methacrylate) resins. One advantage of acrylic resins is the relative ease with which it can be processed. The polymerization process of this resin can be heatactivated, chemical activated, or light-activated. Heat-activated materials are used in the fabrication of nearly all denture bases. ${ }^{2,3}$

During heat activated acrylic denture base fabrication, heat is applied to the resin by immersing a denture flask in a water bath. The water is heated to a prescribed temperature and maintained at that temperature for a period suggested by the manufacturer. The polymerization of denture base resins is exothermic, and the amount of heat evolved can affect the properties of the denture bases. Because resin is an extremely poor thermal conductor, the heat generated in a thick segment of resin cannot be dissipated. When heating is poorly controlled, the peak temperature of this resin can rise well above the boiling point of monomer. This causes boiling of unreacted monomer and produces porosity within the denture bases. ${ }^{3}$

The oral cavity is constantly contaminated by a complex diversity of microbial species that have a strong tendency to colonize surfaces and form biofilm. Biofilm is a dense microbial layer formed by microorganisms and their metabolites. Biofilm formation occurs on all hard surfaces. Denture porosity is a kind of surface roughness that can initiate biofilm formation on denture bases. Accumulation of denture biofilm that consists of oral microbial species can lead to several disorders. Streptococcus mutans are microorganisms of great importance in biofilm formation. ${ }^{4,5}$

Denture stomatitis is a common disorder affectting denture wearer, characterized as inflammation and erythema of the oral mucosal areas covered by denture. Epidemiological studies report prevalence of denture stomatitis among denture wearers to range from $15 \%$ to over $70 \%$. Incidence of denture stomatitis is higher among elderly denture users and women. Etiological factors include poor denture hygiene, continual and overnight wearing of removable partial dentures, accumulation of denture plaque, bacterial and Candida contamination of denture surface. The adhesion of Candida cells to oral surfaces is a key initial event in pathogenesis of oral candidiasis, but there are evidences that denture stomatitis is not a result of Candida albicans solely, but rather it is an outcome of multispecies biofilms that may include Streptococcus mutans and Staphy lococcus aureus. In fact, it has been already observed that coadhesion between Candida albicans and much Streptococcal spp. promotes oral colonization by yeast cells. Streptococcus mutans is a frequent member of acrylic denture base surfaces. ${ }^{6,7}$

To avoid denture stomatitis, patients use a wide variety of agents for cleaning dentures. The most common commercial products are based upon immersion techniques, which is oxygenizing denture cleanser. This denture cleanser agent has several disadvantages such as relatively high cost, biocompatibility issue regarding chemical synthetic component of the solution and the possibility of decreasing its mechanical properties. ${ }^{3,8}$

Chitin is a polysaccharide of animal origin found abundantly in nature and characterized by a fibrous structure. It forms the basis of the main constituent of the outer skeleton of insects and crustaceans like shrimp, crabs and lobsters. Chitosan, a versatile hydrophilic polysaccharide derived from chitin, has a broad antimicrobial spectrum to which gramnegative, gram-positive bacteria and fungi are highly susceptible. The former research has focused on the 
antifungal activity of chitosan $2 \%$ on acrylic resin plate. There for the main objective of this study is to investigate the antibacterial activity of the solutions on acrylic denture plates. ${ }^{9,10}$

\section{MATERIALS AND METHODS}

Fifteen acrylic heat-cured resin specimens were obtained from lost wax technique with the same dimensions $(10 \times 10 \times 2 \mathrm{~mm})$. Acrylic resins were polished and then immersed into three different group solutions with the same amount (five plates each) for chitosan $2 \%$, oxygenizing denture cleanser (Polident ${ }^{\circledR}$ effervescent) and aquadest as control. Chitosan $2 \%$ solution was made by solving and stirring 2 grams chitosan powder to acetic acid $2 \%$ until the volume reach $100 \mathrm{~mL}$. Oxygenizing denture cleanser solutions were made by solving 1 tablet of Polident effervescent into $250 \mathrm{~mL}$ sterile aquadest.

Brain heart infusion agar were made by cooperating 47 grams BHIA into $1 \mathrm{~L}$ aquadest on Erlenmeyer, heated until it boiled and then sterilized on autoclave at $121^{\circ} \mathrm{C}$ for 15 minutes. BHIA solution put into petri disc and let it harden by itself. Streptococcus mutans strains were taken from microbiology laboratory of Medical Faculty, Maranatha Christian University planted by Koch method on blood agar medium and incubated at $37^{\circ} \mathrm{C}$ for 24 hours. ${ }^{11,12}$

After sterilization with autoclave at $121^{\circ} \mathrm{C}$ for 15 minutes each acrylic specimen contaminated one by one by transferring it to a beaker glass containing Streptococcus mutans and incubated at $37{ }^{\circ} \mathrm{C}$ for 24 hours. After 24 hours of incubation period the resins were taken out. These contaminated acrylic resins were transferred to 3 different beakers containing chitosan $2 \%$, oxygenizing denture cleanser and aquadest as control for ten minutes. Beaker glass was vibrated with vortex mixer for 1 minute to release Streptococcus mutans that attached to the resin acrylic plates. Solutions from three different groups were taken and then cooporate to BHIA, put into anaerobic jar and incubated at $37^{\circ} \mathrm{C}$ for 24 hours. Streptococcus mutans colonies counted and tabu-lated. ${ }^{11,12}$

\section{RESULTS}

Chitosan 25 showed to reduce bacterial cell into 0.4 CFU/plate followed by Polident ${ }^{\circledR}$ effervescent with $11 \mathrm{CFU} /$ plate). The effect of all treatments in $S$. mutans was shown in Table 1
Table 1. The mean comparison of Streptococcus mutans colonies number

\begin{tabular}{cccc}
\hline \multicolumn{5}{c}{ Amount of Streptococcus mutans colonies } \\
(CFU/plate)
\end{tabular}

A normality test of the mean comparison of Streptococcus mutans colonies number using Shapiro-Wilk was done following the results to view the normality distribution of the data as shown at table 2.

Table 2. Shapiro-Wilk Test of Normality

\begin{tabular}{|c|c|c|c|c|c|c|c|}
\hline & \multirow[b]{2}{*}{ Group } & \multicolumn{4}{|c|}{$\begin{array}{l}\text { Kolmogorov- } \\
\text { Smirnov }^{\mathrm{a}}\end{array}$} & \multicolumn{2}{|c|}{$\begin{array}{l}\text { Shapiro- } \\
\text { Wilk }\end{array}$} \\
\hline & & $\begin{array}{l}\text { Stati } \\
\text { stic }\end{array}$ & $\mathrm{df}$ & Sig. & $\begin{array}{l}\text { Statist } \\
\text { ic }\end{array}$ & df & Sig. \\
\hline $\begin{array}{l}\text { Repetit } \\
\text { ion }\end{array}$ & $\begin{array}{l}\text { Chitosan } \\
2 \% \\
\text { Polident }^{\circledR} \\
\text { aquadest }^{\circ}\end{array}$ & $\begin{array}{l}.441 \\
.250 \\
.273\end{array}$ & $\begin{array}{l}4 \\
4 \\
4\end{array}$ & & $\begin{array}{r}.630 \\
.919 \\
.893\end{array}$ & $\begin{array}{l}4 \\
4 \\
4\end{array}$ & $\begin{array}{l}.001 \\
.529 \\
.395\end{array}$ \\
\hline
\end{tabular}

Shapiro-Wilk normality test shows that $\mathrm{p}$ value on chitosan $2 \%$ group $(\mathrm{p}=0.001)$ is smaller than 0.005 , this means the data was not distributed normally. Based on this result, statistically analysis continued with Kruskal-Wallis non-parametric test followed by Mann-Whitney test, as shown in table 3 and 4.

Table 3. Non-parametric Kruskal Wallis Test

\begin{tabular}{ll}
\hline & Repetition \\
\hline Chi-square & 8.858 \\
\hline Df & 2 \\
\hline Asymp. Sig. & .012
\end{tabular}

Kruskal-Wallis test shows $\mathrm{p}=0.012(\mathrm{p}<0.05)$, this means there is at least one group having significance differential of Streptococcus mutans colonies number. Mann-Whitney test shows which groups having significance differential with the control group which are chitosan $2 \%$ and Polident ${ }^{\circledR}$ groups, as shown in table 4. 
Table 4. Mann-Whitney Test

\begin{tabular}{|c|c|c|c|}
\hline Groups & $\begin{array}{l}\text { Chitosan } \\
2 \%\end{array}$ & Polident $^{\circledR}$ & Aquadest \\
\hline $\begin{array}{l}\text { Chitosan } \\
2 \%\end{array}$ & & $0.091^{\mathrm{TB}}$ & $0.018^{*}$ \\
\hline Polident ${ }^{\circledR}$ & & & $0.021^{*}$ \\
\hline \multicolumn{4}{|l|}{ Aquadest } \\
\hline $\begin{array}{l}* \text { : Un-sign } \\
\text { TB: Signi } \\
\text { P value < } \\
\text { significan }\end{array}$ & $\begin{array}{l}\text { nce } \\
\text { ce } \\
\text { very sign }\end{array}$ & nce; $\mathrm{P}$ valu & 05: \\
\hline
\end{tabular}

\section{DISCUSSION}

This study compared the efficacy of two dental cleaners' solution on contaminated specimens. Among three solutions evaluated against Streptoco ccus mutans, chitosan $2 \%$ solution demonstrated more effective in antimicrobial effect on heat-cured acrylic denture base resin. Heat polymerized acrylic resin was chosen because its low porosity incidence and ease of manipulation. Despite of this advantages heat-cured acrylic resins still have micro surface irregularity that can initiate biofilm formation causing soft tissue disorder such as denture stomatitis. ${ }^{411}$ The statistical analysis results shows that chitosan $2 \%$ solution have a significant effect on prohibiting the growth of Streptococcus mutans colonies on acrylic heat-cured plates, however a statistically significant difference between the two groups was not observed.

Oxygenizing denture cleansers are marketed in powder and tablets forms containing alkaline compounds, detergents, sodium perborate, and flavourring agents. Dissolved in water, sodium perborate decomposes to form an alkaline peroxide solution. This solution subsequently releases oxygen, which loosens debris via mechanical means. Although this denture cleansers agent is frequently used there are several disadvantages such as high cost and biocompatibility issue regarding chemical synthetic component of the solution. ${ }^{3}$

\section{REFERENCES}

1. Suresh S, Sharma S. A clinical survey to determine the awareness and preference of needs of a complete denture among complete edentulous. J. Int. Oral Health 2010; 2(3): 65-70

2. Carr AB, McGivney GP, Brown DT. McCracken's removable partial prosthodontics. 13th ed., St. Louis: CV Mosby, 2015: 29-55
Chitosan (1-4, 2-amino-2-deoxy- $\beta$-D-glucan) is a biodegradable, biocompatible, and low toxicity substance that useful and convenient in many medical applications mostly based on its antimicrobial properties among others. Antimicrobial properties of cationic polymers have been known for a long time. Some studies have demonstrated the disruption of bacterial membranes by chitosan solution. Polycationic chitosan can interact with the negatively charged membrane and alter bacterial surface morphology, which either increases membrane permeability, causing leakage of intracellular substances, or decreases membrane functions, preventing nutrient transport. Three antibacterial mechanisms have been proposed, the ionic surface interaction resulting in wall cell leakage, the inhibition of the mRNA and protein synthesis via the penetration of chitosan into the nuclei of the microorganisms, and the formation of an external barrier, chelating metals and provoking the suppression of essential nutrients to microbial growth. ${ }^{13}$

This study shows that chitosan $2 \%$ solution can effectively prohibit the growth of Streptococcus mutans colonies on heat-cured acrylic resin plates better than oxygenizing denture cleaner due to its antimicrobial properties. The concentration of $2 \%$ chitosan chooses because it considered as the optimum concentration to effectively prohibit bacterial growth without causing any unwanted biological effect to the underlying oral tissues. ${ }^{10}$

The conclusion, Chitosan $2 \%$ can prohibit the growth of Streptococcus mutans contaminated heatcured resin acrylic better than oxygenizing denture cleansers Polident $^{\circledR}$ however a statistically significant difference between the two groups was not observed. Further studies needed to test the cytotoxicity of chitosan $2 \%$ solution and compare it antimicrobial effectiveness with other concentrations.

\section{Acknowledgements}

This study was supported by Advanced Material Engineering Laboratory of Bandung Institute of Technology.

3. Anusavice KJ, Chiayi S, H Ralph R. Phillips' science of dental materials. 12th ed, Singapore: Elsevier, 2013: 474-97

4. Gharechahi M, Moosavi H, Forghani M. Effect of surface roughness and materials composition on biofilm formation. J Biomater and Nanobiotechnol 2012; 3: 541-6 
5. Goncalves RF, Ingrid MA, Claudia HSL, Helena FOP, Fabiana CP, Izabel YI. Prevalence of mutans streptococci isolated from complete dentures and their susceptibility to mouthrinses. Braz Dent J 2011; 22(1): 62-7

6. Gendreau L, Zvi GL. Epidemiology and etiology of denture stomatitis. J Prosthodont 2011; 20(4): 25160

7. Vasconcelos LC, Fabio CS, Maria CCS, Maria SVP, Maria HPP. Streptococcus mutans in denture stomatitis patients under antifungal therapy. Rev Odonto Cienc 2010; 25(21): 120-5

8. Pisani MX, Claudia HLS, Helena FOP, Raphael FS, Ana PM. The effect of experimental denture cleanser solution ricinus communis on acrylic resin properties. J Mat Res 2010; 13(3): 369-73
9. Goy RC, Britto DB, Assis OBG. A review of the antimicrobial activity of chitosan. Polimeros 2009; 19(3): 241-7

10. Evelyna A, Dahlia S, Elizabeth T. Chitosan 2\% effect on prohibiting the growth of candida albicans on heatcured acrylic resin. J Material Kedokteran Gigi 2017; 2(6): 17-24

11. Sahin C, Simel A, Alper E, Gulay U. Effect of chemical denture cleansers on microorganisms over heat-polymerized acrylic resin. African $\mathbf{J}$ of Dentistry 2013; 1(2): 6-9

12. Balaji S, Muralidharan NP. Effectiveness of 4 different disinfectants in removing 2 microorganisms from acrylic resins. J Pharm Sci Rev Res 2016; 40(2): 83-5

13. Pena A, Sanchez NS, Calahorra M. Effects of chitosan on Candida albicans: conditions for its antifungal activity. Biomed Res Int 2013; 2013: 1-16 